\title{
Composite Immersion and Invariance Based Adaptive Attitude Control of Asteroid-Orbiting Spacecraft in Elliptic Orbit
}

\section{Research Article}

Keywords:

Posted Date: March 30th, 2021

DOI: https://doi.org/10.21203/rs.3.rs-304417/v2

License: (c) (1) This work is licensed under a Creative Commons Attribution 4.0 International License. Read Full License 


\section{Abstract}

The authors have requested that this preprint be withdrawn due to author disagreement.

\section{Full Text}

The authors have withdrawn this preprint from Research Square. 